\title{
Pembinaan Pengendalian Manajemen Keuangan Dengan Aplikasi ABSS Accounting Pada UKM Bank Sampah Mandiri
}

\author{
Syahril Effendi*, Tukino $^{2}$, Algifanri Maulana ${ }^{3}$ \\ ${ }^{1}$ Jurusan/Program Studi Akuntansi, Fakultas Ilmu Sosial dan Humaniora \\ ${ }^{2}$ Jurusan/Program Studi Sistem Informasi, Fakultas Teknik dan Komputer \\ ${ }^{3}$ Jurusan/Program Studi Teknik Informatika, Fakultas Teknik dan Komputer \\ ${ }^{1,2,3}$ Universitas Putera Batam, Jalan R. Soeprapto Muka Kuning, Kibing, Kec. Batu Aji, \\ Kota Batam, Kepulauan Riau 29434 \\ *e-mail : syahril@puterabatam.ac.id
}

Informasi Artikel

Diterima Redaksi: 25 Desember 2021

Revisi Akhir: 29 Desember 2021

Diterbitkan Online: 15 Januari 2021

Kata Kunci:

Pembinaan; Pengendalian Manajemen Keuangan; Aplikasi ABSS

\section{PENDAHULUAN}

Kota Batam adalah Kota terbesar di Kepulauan Riau dan merupakan Kota dengan populasi terbesar ke tiga di wilayah Sumatera Setelah Medan dan Palembang. Menurut [1] jumlah penduduk Batam mencapai 1.153.860 jiwa. Metropolitan Batam terdiri dari tiga pulau, yaitu Batam, Rempang dan Galang yang dihubungkan oleh Jembatan Barelang. Batam merupakan salah satu Kota dengan pertumbuhan terpesat di Indonesia. Ketika dibangun pada tahun 1970-an awal Kota ini hanya dihuni sekitar 6.000 penduduk dan dalam tempo 40 tahun penduduk Batam bertumbuh hingga 158 kali lipat.

\section{Abstrak}

Berdasarkan hasil wawancara permasalahan
Perusahaan-perusahaan kecil atau menengah yang tidak menggunakan software akuntansi untuk mencatat pembukuannya. Cara tradisional pencatatan keuangan secara manual masih sering digunakan karena kurangnya sumber daya manusia yang memiliki keahlian atau skill dibidang akuntansi serta memakan biaya untuk pembelian peralatan komputer dan software pada sistem komputerisasi pada badan-badan usaha kecil tersebut. UKM perlu dilatih membuat pembukuan, sehingga nantinya bisa memisahkan bagian modal yang digunakan untuk operasional usaha dan bagian uang yang dapat digunakan untuk keperluan sehari-hari. Metode yang digunakan dalam pembinaan UKM Bank Sampah Mandiri di Sagulung - Kota Batam Kota Batam yang akan diberikan yaitu metode survei, metode ceramah, metode diskusi dan metode latihan. Keberlanjutan dari hasil kegiatan pembinaan yaitu diharapkan UKM Bank Sampah Mandiri di Sagulung Kota Batam mampu memahami pencatatan serta tujuan dalam catatan laporan keuangan, mampu menganalisis dan membuat laporan keuangan secara mandiri sesuai dengan siklus akuntansi setiap periodenya, mampu menyusun laporan keuangan dengan bantuan program ABSS Accounting, dapat meningkatkan kinerja keuangan UKM Bank Sampah Mandiri di Sagulung Kota Batam.

Batam merupakan salah satu Kota industri yang terbesar diantara beberapa Kota yang ada di Indonesia. Batam adalah satu Kota yang sudah terkenal keseluruh pelosok negeri di Indonesia. Bicara bisnis di Kota Batam sudah tidak asing bagi masyarakat, segala bisnis ada di Kota Batam, baik itu industri, home industri, dan berdirinya berbagai perusahaan kecil dan besar, kini Kota Batam salah satu terbesar untuk anggaran pendapatan belanja daerah, sebagai bukti Kota Batam sudah menjadi Kota pusat dari segala bisnis. Usaha kecil menengah yang merupakan usaha yang ditekuni oleh masyarakat saat ini dan banyak menyerap tenaga kerja [2]. 
Berdasarkan hasil penelitian [4] yang berjudul "Accounting Practises of SMES in Zimbabwe : An Investigative Study of Record Keeping for Performance Measurement" bahwa 50\% Usaha Mikro Kecil dan Menengah tidak menyimpan lengkap catatan akuntansi karena kurangnya pengetahuan akuntansi dan penggunaan informasi akuntansi sehingga tidak dapat dilakukan pengukuran kinerja keuangan usaha. Sama halnya dengan hasil penelitian [3] yang berjudul "Accounting Practices of SMES: A Case Study of Kumasi Metropolis in Ghana" bahwa 60\% UMKM mengalami kesulitan untuk akses keuangan dari lembaga keuangan karena UMKM tersebut tidak memiliki catatan keuangan yang tepat. Oleh karena itu disarankan pada UMKM untuk membuat dan menyimpan catatan akuntansi yang rinci. Sehingga menghasilkan laporan keuangan yang tepat dan dapat meningkatkan aksessibilitas UMKM terhadap lembaga keuangan mikro.

Di Kota Batam, Usaha Kecil Menengah Kelompok Usaha Bersama (KUBE) Snack dan Cookies yang bertempat tinggal di Kavling Lama Sagulung Bersatu RT. 02 RW. 09 Blok D Nomor 11. UKM Bank Sampah Mandiri di Sagulung - Kota Batam menjual beraneka ragam makanan ringan kue basah, kue bolu brownies dan beraneka ragam jenis keripik.

Perpindahan pusat pemerintahan, pemukiman masyarakat menyebabkan semakin berkembangnya Usaha Kecil dan Menengah (UKM) di Kota Batam. Jenis industri yang berkembang ada seperti industri makanan, minuman, pengrajin, dan jasa. Sebagian besar usaha kecil tumbuh secara tradisional dan merupakan usaha keluarga yang turun temurun. Keterbatasan Sumber Daya Manusia (SDM) usaha kecil baik dari segi pendidikan formal maupun pengetahuan dan keterampilannya sangat berpengaruh terhadap manajemen pengelolaan usahanya, sehingga usaha tersebut sulit untuk berkembang dengan optimal. Disamping itu dengan keterbatasan SDM-nya, unit usaha tersebut relatif sulit untuk mengadopsi perkembangan teknologi baru untuk meningkatkan daya saing produk yang dihasilkannya. Melihat dari perkembangan di Kota Batam dan pertumbuhan usaha kecil yang ada di Kota Batam. Maka dari itu program ilmu pengetahuan dan teknologi bagi Masyarakat ini ditujukan kepada usaha kecil yang berada di wilayah Kota Batam.

UKM Bank Sampah Mandiri di Sagulung - Kota Batam adalah usaha kue basah dan snack makanan ringan dengan nama usaha Snack dan Cookies, Usaha Snack dan Cookies yang dimiliki oleh Ibu Elis Sriyani beralamat di Kavling Lama Sagulung Bersatu RT.02 RW.09 Blok D 11, Batu Aji Batam. Usaha ini merupakan Usaha Snack dan Cookies (makanan ringan) yang sudah berdiri dari tahun 2013. UKM Bank Sampah Mandiri di Sagulung - Kota Batam menjual berbagai jenis kue basah dan keripik. Harga jual yang dipasarkan untuk kue basah dari Rp 2.000 sampai dengan $\mathrm{Rp} 5.000$, sedangkan browniesnya $\mathrm{Rp}$ 25.000. Dengan tenaga kerja sebanyak 10 orang, yaitu 5 orang yang bagian membuat kue basah dan 5 orang lagi bagian membuat aneka keripik. Pada saat musim Seleksi Tilawatil Quran (STQ) dipasarkan kue basah dan keripik kurang lebih banyak laku terjual hingga 50 pcs kue basah, brownies dan keripik. Sedangkan dalam sebulan yang laku terjual dari pesanan hanya sekitar 20 sampai 30 pcs. Dalam sebulan omset yang didapatkan kurang lebih Rp 400.000 sampai dengan $\mathrm{Rp}$ 500.000 .

Permasalahan Perusahaan-perusahaan kecil atau menengah yang tidak menggunakan $M Y O B$ Accounting untuk mencatat pembukuannya. Cara tradisional pencatatan keuangan secara manual masih sering digunakan karena kurangnya sumber daya manusia yang memilki keahlian atau skill dibidang akuntansi serta memakan biaya untuk pembelian peralatan komputer dan software pada sistem komputerisasi pada badan-badan usaha kecil tersebut. Bahkan ada perusahaan yang tidak memiliki sistem pembukuan sama sekali sejak puluhan tahun mulai berdirinya usaha tersebut. Padahal hal ini dapat menjadi salah satu penghambat dalam perkembangan usaha yang bersangkutan.

Pembukuan keuangan atau sistem akuntansi pada usaha kecil menengah dalam skala terkecil sekalipun mutlak dibutuhkan walaupun banyak pengusaha konvensional menganggapnya sebagai hal yang merepotkan. Pembukuan baik secara sederhana atau pun dengan menggunakan 
$M Y O B$ Accounting seharusnya tak perlu menjadi hal yang membebani karena catatan inilah yang dapat menjadi bukti tentang aktivitas perusahaan juga sebagai informasi keberlangsungan kegiatan kepada pemerintah.

Manfaat lain dari pembuatan pembukuan adalah memudahkan jalannya bisnis, sebagai dasar untuk melakukan analisis perkembangan bisnis, memudahkan UKM untuk meyakinkan pihak lain bila ingin menjalin kerja sama dan kemitraan, membuktikan kredibilitas perusahaan dalam pengajuan kredit.

Beberapa UKM yang berhasil mengembangkan usahanya menjadi skala yang lebih besar telah membuktikan bahwa kekurangan-kekurangan UKM ternyata dapat dipecahkan dengan menggunakan sistem informasi melalui komputerisasi. Untuk dapat merealisasikan hal ini tentu dibutuhkan pengaplikasian software $M Y O B$ Accounting sebagai sarana untuk membuat laporan keuangan yang akurat dan dapat dipertanggungjawabkan. Untuk dapat menggunakan fasilitas berbasis teknologi canggih ini dibutuhkan sumber daya manusia yang memahami dibidangnya dan salah satu cara untuk mewujudkannya adalah dengan melakukan pembinaan pengelolaan keuangan dengan aplikasi $A B S S$ Accounting pada UKM Bank Sampah Mandiri di Sagulung - Kota Batam.

Permasalahan yang sedang dihadapi Industri makanan ringan snack dan cookies, berdasarkan survei yang dilaksanakan adalah:

a) Minimnya pengetahuan tentang pembukuan keuangan sesuai standar entitas tanpa akuntabilitas publik (SAK-ETAP) untuk para pelaku UKM Bank Sampah Mandiri di Sagulung Kota Batam.

b) Belum ada pemisahan pembukuan keuangan pribadi dengan pencatatan usaha terkait belanja bahan, proses produksi sampai ke pemasaran, sehingga harga dan omset terbentuk hanya berdasarkan perkiraan.

c) Minimnya pengetahuan dan pemahaman UMKM dalam teknologi informasi dengan berbasis teknologi yang canggih (Software Accounting). Karena kurangnya sumber daya manusia yang memiliki keahlian atau skill dibidang akuntansi dan dibidang komputerisasi serta dianggap memakan biaya untuk pembelian peralatan komputer dan software ABSS Accounting di UKM Bank Sampah Mandiri di Sagulung Kota Batam.

\section{METODE}

Kegiatan pengabdiaan masyarakat dengan melakukan pembinaan akan dilaksanakan selama 2 Bulan (Dari Bulan Januari-Februari 2020), pada minggu ke 3 dan minggu ke 4 pada bulan Januari 2020 dan minggu ke 1 dan minggu ke 2 bulan Februari 2020, dimana kegiatan kunjungan untuk memberikan latihan pembinaan diberikan sebanyak 5 kali. Pada hari Senin dan Kamis pukul 13.00 WIB sampai dengan 15.30 WIB yang bertempat di Sagulung Bersatu RT.02 RW.09 Kelurahan Sei Lekop Kecamatan Sagulung Kota Batam.

Pelaksanaan kegiatan Pengabdian Pada Masyarakat ini dilakukan dengan menggunakan metode ceramah, tutorial, dan diskusi serta latihan. Adapun sistematika pelaksanaan kegiatan pengabdian ini adalah sebagai berikut:

a. Langkah Pertama (Metode Ceramah):

Peserta diberikan motivasi agar memiliki kemauan untuk menggunakan akuntansi dalam kegiatan bisnisnya. Selain itu, peserta diberikan materi gambaran umum tentang akuntansi UKM dan peran penting akuntansi bagi UKM. Langkah pertama diselenggarakan selama 1 jam.

b. Langkah kedua (Metode Tutorial):

Peserta pelatihan diberikan materi akuntansi mulai dari pencatatan sampai dengan menyusun laporan keuangan dengan bantuan program ABSS Accounting. Langkah kedua diselenggarakan selama 2 jam.

c. Langkah ketiga (Metode Diskusi):

Peserta pelatihan diberikan kesempatan untuk mendiskusikan permasalahan yang berkaitan dengan keuangan dan teknologi informasi UKM yang selama ini dihadapi. Langkah ketiga diselenggarakan selama 1 jam.

d. Langkah keempat (Metode Latihan)

Kegiatan pembinaan ini dilakukan untuk membina serta melatih para pelaku UKM dalam menganalisa transaksi-transaksi secara nyata hingga proses penyusunan laporan keuangan. Tujuan laporan keuangan 
ini disajikan bukan hanya pihak internal saja tetapi juga pihak eksternal terutama jika usaha kecil menengah ingin memperluas usahanya untuk menambah modal dengan melakukan pinjaman kepada pihak debitur serta pengembangan usahanya.

Keberlanjutan dari hasil kegiatan pembinaan pada UKM Bank Sampah Mandiri di Sagulung - Kota Batam setelah dilakukan kegiatan pembinaan ini oleh tim pengabdian masyarakat hendaknya memiliki nilai positif diberbagai pihak terutama pihak usaha kecil menengah dalam keuangan perusahaan mereka. Penguasaan akuntansi dan teknologi informasi dengan mudah dan cepat akan memberikan manfaat bagi mereka dalam hal pengelolaan keuangan. Penyajian pelatihan akuntansi yang mendasarkan pada keadaan yang sebenarnya di dalam bisnis UKM dan penggunaan pendekatan yang tepat akan menjadikan pelaku UKM memahami akuntansi dan teknologi informasi secara mudah dan cepat. Pemahaman terhadap akuntansi diharapkan akan membantu pelaku UKM untuk mengelola sumber dana dan penggunaan secara cermat dan efisien sehingga UKM Bank Sampah Mandiri di Sagulung - Kota Batam dapat berkembang lebih baik dan dapat meningkatkan kinerja keuangan.

Adapun keberlanjutan kegiatan ini sebagai berikut:

a) UKM Bank Sampah Mandiri di Sagulung - Kota Batam mampu memahami pencatatan serta tujuan dalam catatan laporan keuangan.

b) UKM Bank Sampah Mandiri di Sagulung - Kota Batam mampu menganalisis dan membuat laporan keuangan secara mandiri sesuai dengan siklus akuntansi setiap periodenya.

c) UKM Bank Sampah Mandiri di Sagulung - Kota Batam mampu menyusun laporan keuangan dengan bantuan program ABSS Accounting.

d) Laporan keuangan yang telah disusun berdasarkan SAK-ETAP serta dapat meningkatkan kinerja keuangan UKM Bank Sampah Mandiri di Sagulung Kota Batam serta diharapkan dapat mengelola keuangan usahanya.

e) UKM Bank Sampah Mandiri di Sagulung - Kota Batam mampu mengklasifikasikan pencatatan keuangan pribadi dengan pencatatan keuangan usahanya.

Keberlanjutan dari hasil kegiatan pembinaan pada UKM Bank Sampah Mandiri di Sagulung - Kota Batam setelah dilakukan kegiatan pembinaan ini oleh tim pengabdian masyarakat hendaknya memiliki nilai positif diberbagai pihak terutama pihak usaha kecil menengah dalam keuangan perusahaan mereka. Penguasaan akuntansi dan teknologi informasi dengan mudah dan cepat akan memberikan manfaat bagi mereka dalam hal pengelolaan keuangan. Penyajian pelatihan akuntansi yang mendasarkan pada keadaan yang sebenarnya di dalam bisnis UKM dan penggunaan pendekatan yang tepat akan menjadikan pelaku UKM memahami akuntansi dan teknologi informasi secara mudah dan cepat. Pemahaman terhadap akuntansi diharapkan akan membantu pelaku UKM untuk mengelola sumber dana dan penggunaan secara cermat dan efisien sehingga UKM Bank Sampah Mandiri di Sagulung - Kota Batam dapat berkembang lebih baik dan dapat meningkatkan kinerja keuangan.

Adapun keberlanjutan kegiatan ini sebagai berikut:

a) UKM Bank Sampah Mandiri di Sagulung-Kota Batam mampu memahami pencatatan serta tujuan dalam catatan laporan keuangan.

b) UKM Bank Sampah Mandiri di Sagulung-Kota Batam mampu menganalisis dan membuat laporan keuangan secara mandiri sesuai dengan siklus akuntansi setiap periodenya.

c) UKM Bank Sampah Mandiri di Sagulung-Kota Batam mampu menyusun laporan keuangan dengan bantuan program ABSS Accounting.

d) Laporan keuangan yang telah disusun berdasarkan SAK-ETAP serta dapat meningkatkan kinerja keuangan UKM Bank Sampah Mandiri di Sagulung Kota Batam serta diharapkan dapat mengelola keuangan usahanya.

e) UKM Bank Sampah Mandiri di Sagulung-Kota Batam mampu mengklasifikasikan pencatatan keuangan pribadi dengan pencatatan keuangan usahanya. 
3. HASIL DAN PEMBAHASAN

\section{a. Hasil Pengabdian}

Pengabdian masyarakat yang berupa pembinaan telah direalisasikan sebanyak 5 kali pertemuan yang dilaksanakan setiap pukul 14.00 sampai dengan 17.00 WIB. Pembinaan dilakukan oleh 7 orang dari ibuibu kelompok UKM Bank Sampah Mandiri. Teknis pelaksanaan pembinaan dilakukan dengan metode ceramah, diskusi dan latihan penyusunan laporan Keuangan. Berdasarkan metode tersebut maka Tim pengabdi secara langsung memandu dan membina UMKM dalam penyusunan laporan keuangan sesuai dengan SAK-ETAP yang benar dengan bantuan ABSS (Asian Business Software Solution). Adapun penjelasan pada setiap pertemuan sebagai berikut:

a) Pertemuan Pertama, Kedua dan Ketiga

Pelaksanaan pengabdian masyarakat pertemuan pertama dilaksanakan setiap hari Selasa, 7, 14 dan 21 Januari 2020, dimana kegiatan pertemuan saat itu diawali dengan pembukaan oleh Ketua, dilanjutkan penyampaian materi topik materi Pengantar Akuntansi UMKM disertai pengantar pembukuan yang menggunakan ABSS Accounting. Materi ini membahas pentingnya akuntansi UMKM disertai membahas soal terkait transaksi UMKM serta membahas soal dan jawaban pelaporan keuangan. Kegiatan ini disampaikan oleh Ketua.

Materi kedua dan ketiga ini juga disampaikan oleh 2 Anggota Dosen dan dibantu oleh 4 Anggota Mahasiswa dengan topik pengisian nama akun perusahaan, nama pelanggan, nama pemasok, daftar utang, daftar piutang pelanggan UMKM dengan bantuan menggunakan bantuan aplikasi computer dalam program ABSS (Asian Business Software Solution) untuk mempermudah penginputan data keuangan dalam mempraktekannya. Sedangkan materi ketiga yang disampaikan oleh 2 Anggota Dosen terkait transaksi-transaksi keuangan.

b) Pertemuan Keempat dan Kelima

Pelaksanaan pengabdian masyarakat pertemuan kedua dilaksanakan setiap hari Rabu, 5 dan 12 Februari 2020. Kegiatan pertemuan ini berupa penjelasan topik praktik akuntansi UMKM dengan ABSS Accounting dan pencatatan kartu persediaan usaha UMKM yang disampaikan oleh Ketua pada pukul 14.00 serta dilanjutkan oleh
Anggota 1 terkait penjelasan materi laporan keuangan yang terdiri dari laporan laba rugi, laporan posisi keuangan, laporan perubahan ekuitas seta transaksi pembelian dan transaksi penjualan. Pada materi laporan laba rugi dan laporan posisi keuangan dibahas jawabannya serta paparannya oleh Ketua. Kemudian setelah itu selesai pada pukul 15.00 sampai dengan 16.00 WIB dilanjutkan pembahasan materi dan contoh soal terkait laporan perubahan ekuitas yang disampaikan oleh Anggota 1 seta membahas transaksi yang sehari-hari terjadi di usaha UMKM yaitu transaksi pembelian dan transaksi penjualan. Tepat pada jam 16.00 Tim pengabdi memberikan sesi latihan terkait transaksi bisnis UMKM secara mandiri yang didampingi oleh 2 Anggota Dosen dan 4 Anggota Mahasiswa. Tujuannya agar mendapatkan feedback dari yang sudah disampaikan.

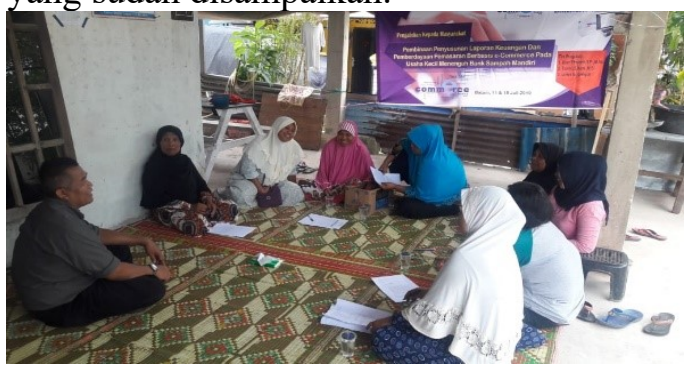

Gambar 1 Pemaparan Materi Oleh Dosen

Selanjutnya sisa pembinaan peserta diberikan kesempatan untuk mendiskusikan permasalahan yang berkaitan dengan usaha yang sudah mereka jalani yang didampingi oleh Ketua, 2 Anggota Dosen dan 4 Anggota Mahasiswa.

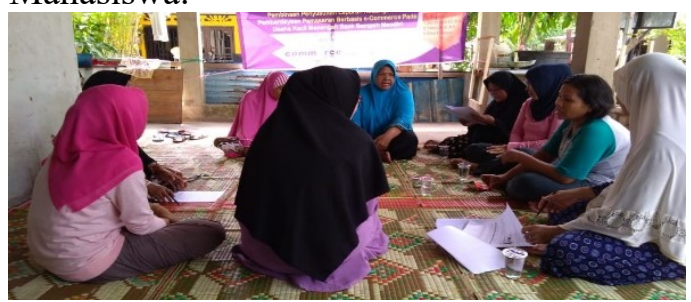

Gambar 2 Diskusi Dengan Peserta PKM

b. Pembahasan

Kegiatan yang sudah dilaksanakan sebanyak 2 kali pertemuan dapat dijelaskan bahwa kegiatan dapat dijalankan sesuai dengan rencana. Dosen dan satu orang mahasiswanya yang memberikan bantuan kepada UKM dalam penyusunan laporan keuangan dengan aplikasi ABSS Accounting. Materi pertama yang diberikan 
adalah pengenalan atau pendahuluan mengenai akuntansi. Pemateri memberikan penjelasan pentingnya akuntansi bagi UMKM serta membahas materi dan soalsoal dari jurnal umum sampai dengan laporan keuangan. Sebagian besar audiens belum mengerti fungsi akuntansi, bahkan sebagian besar peserta pembinaan menganggap bahwa akuntansi adalah bidang yang rumit, susah, merepotkan, menghabiskan waktu.

Materi pertama diisi dengan penguatan pentingnya akuntansi bagi usaha kecil (UMKM) dan data-data transaksi yang harus dimasukan didalam jurnal umum. Pada sesi ini terjadi diskusi yang menarik antara audience dengan pemateri mengenai konsep dasar usaha terkait usaha yang UKM tekuni. Dilanjutkan materi kedua mengenai transaksi-transaksi akuntansi UMKM yaitu transaksi pembelian dan transaksi penjualan. Pada sesi ini, masing-masing audience diminta menjelaskan juga saldo awal buku pembantu piutang (customer balances) dan saldo awal buku besar pembantu utang (supplier balances) di masing-masing usaha mereka. Selanjutnya diidentifikasi aktivitasaktivitas ekonomi terkait pencatatan akuntansi. Aktivitas yang diidentifikasi tersebut diawali dari aktivitas memulai usaha (investasi awal), transaksi pembelian bahan baku, pembelanjaan atau pengeluaran, pemasukan atau penerimaan. Setelah mencatat transaksi akuntansi, materi berikutnya menyusun laporan keuangan. Sebagai latihan, peserta pembinaan diminta untuk menjawab soal latihan yang telah disediakan oleh Tim Pengabdi dengan menjawabnya menggunakan bantuan aplikasi ABSS Accounting. Sesi terakhir peserta diberikan diskusi terkait pencatatan keuangan di usaha UKM.

Pembinaan hari kedua dilaksanakan hari Rabu, 24 Juli 2019, peserta diberikan gambaran tentang materi dan praktik laporan keuangan yang terdiri dari laporan laba rugi, laporan perubahan ekuitas serta transaksi pembelian dan transaksi penjualan. Pada sesi awal peserta bertanya dan berdiskusi tentang transaksi dan pencatatan yang telah mereka buat. Beberapa dari peserta masih kebingungan mencatat transaksi akuntansi. Sambil beristirahat dan menyantapi Snack yang ada, diskusi dilanjutkan membahas penyusunan laporan keuangan dalam prakteknya. Serta sisa waktu pukul 16.00 WIB pembinaan digunakan untuk pendampingan kepada peserta pembinaan akuntansi UMKM secara mandiri dimasingmasing tempat untuk menjawab latihan yang telah disediakan Tim Pengabdi.

Pelaksanaan pengabdian yang dilaksanakan ditemukan kendala yang signifikan, namun dapat diatasi setelah kegiatan dilaksanakan sampai selesai, kendala yang terjadi adalah:

a) Sebagian besar peserta menyusun laporan keuangan belum sesuai standar akuntansi keuangan entitas tanpa akuntabilitas publik.

b) Belum ada pemisahan laporan keuangan yang telah biasa disusun oleh UKM melalui keuntungan usaha dan kas pribadi.

c) Penginputan data keuangan dengan menggunakan aplikasi ABSS Accounting tidak bisa diganti secara langsung.

Permasalahan yang dihadapi Tim Pengabdi diatas dapat dievaluasi dengan cara sebagai berikut:

a) Pelaksanaan ini dapat dijelaskan secara continue, sampai dengan usaha kecil menengah mengerti dengan penjelasan setiap pertemuan yang dilaksanakan sampai dengan UKM Bank Sampah Mandiri dapat secara mandiri menyusun laporan keuangan usaha mereka dengan akuntansi keuangan entitas tanpa akuntabilitas publik.

b) Perbedaan antara keuntungan usaha dan kas pribadi dapat dipraktekan di transaksi yang terjadi di sehari-hari, sehingga terlihat perbedaan catatan keuangan usaha dengan catatan keuangan pribadi.

c) Laporan keuangan UKM yang mulanya disusun menggunakan manual dengan buku besar yang hanya mencatat berapa pemasukan dan pengeluaran. Dengan perkembangan dunia maka dari itu UKM juga dituntut untuk mau mempelajari penginputan data keuangan dengan bantuan software Accounting "ABSS Accounting". Tim pengabdi melakukan pembinaan penginputan data keuangan dengan dasarnya yaitu bantuan ABSS Accounting secara praktek mandiri per 7 orang dari kelompok UKM Bank Sampah Mandiri. 
d) Tim pengabdi selalu melakukan koordinasi dan berkomunikasi serta mengevaluasi setiap selesai kegiatan pengabdian masyarakat. Pelaksanaan evaluasi kegiatan dilakukan untuk mengetahui kendala yang dihadapi saat pengabdian dilaksanakan. Hasil evaluasi akan ditindaklanjuti sesuai dengan kendala yang sedang dihadapi.

\section{KESIMPULAN}

Berdasarkan penjelasan hasil dan pembahasan, maka didapatkan simpulan sebagai berikut:

a) Usaha Kecil Menengah (UKM) yang sudah dibina dapat melakukan penyusunan laporan keuangan secara mandiri, sehingga UKM Bank Sampah Mandiri mampu menyusun laporan keuangan berstandar SAK-ETAP.

b) Kegiatan pembinaan akuntansi UMKM bagi usaha mikro, kecil, menengah dalam pemisahan keuntungan sistem keuangan usaha dan kas pribadi, perlu adanya latihan-latihan keberlanjutan dalam keuangan usaha dan kas pribadi sehari-hari.

c) Pelaku Usaha Kecil Menengah (UKM) Snack dan Cookies yang telah dibina dalam penyusunan laporan keuangan dengan bantuan ABSS Accounting, perlu adanya latihan-latihan secara mandiri dalam prakteknya sehari-hari yang dilakukan ibu-ibu UKM dalam hal penginputan data keuangan dengan sistem ABSS Accounting. Agar dapat membiasakan dalam kebutuhan usahanya sehari-hari.

\section{SARAN}

Berdasarkan kesimpulan kegiatan di atas, maka disarankan kepada semua pihak agar terutama bagi:

a) Bagi Pelaku Usaha Kecil Menengah diharapkan dapat menerapkan penyusunan laporan keuangan sesuai dengan standar akuntansi yang diterapkan saat ini serta dapat menginputnya langsung ke dalam ABSS Accounting yang memiliki fungsi dan manfaat buat internal dan eksternal atau semua pihak-pihak yang berkepentingan.

b) Tim Pengabdi yang akan melaksanakan pengabdian berikutnya, maka disarankan dapat dilaksanakan kembali dengan peserta (audience) yang lebih banyak atau luas, dengan topik pajak penghasilan UMKM yang harus dibayarkan, mengingat UMKM akan dikenai pajak sebesar 0,5 sampai dengan $2 \%$ dari total omsetnya melalui penginputan data keuangan dengan bantuan software ABSS Accounting.

\section{UCAPAN TERIMA KASIH}

Terima kasih kepada LPPM Universitas Putera Batam sebagai pemberi dana dalam pengabdian ini sehingga pengabdian ini dapat terlaksana dengan baik. Terima kasih kepada UKM Bank Sampah Mandiri yang menjadi objek pengabdian penulis

\section{REFERENSI}

[1]. Dinas, \& Kependudukan. (2015). Catatan Sipil Kota Batam, Jumlah Penduduk Batam. Kota Batam.

[2]. Jusup. A. H. (2012). Dasar-Dasar Akuntansi Jilid 1 Edisi 5. Yogyakarta: Bagian Penerbitan STIE YKPN.

[3]. Kementrian, \& Koperasi. (2014). Batam Dalam Angka. Kota Batam.

[4]. Kwabena. (2013). Accounting Practices of SMES: A Case Study of Kumasi Metropolis in Ghana. International Journal of Business and Management, 8(24), 21-29. https://doi.org/10.5539

[5]. Maseko, M. (2011). Accounting Practices of SMES in Zimbabwe: An Investigative Study of Record Keeping for Performance Measurement. Journal of Accounting and TaxationNo Title. Journal of Accounting and Taxation, $3(8)$, 171-181. https://doi.org/10.5897/JAT.11031.

[6]. Mardiasmo. (2010). Akuntansi Keuangan Dasar Jilid 1 Edisi 3. Yogyakarta: BPFE UGM.

[7]. Mulyadi. (2013). Sistem Akuntansi Edisi 3. Yogyakarta: Bagian Penerbitan STIE YKPN.

[8]. Tunggal, A. W. (2013). Akuntansi Untuk Perusahaan Kecil dan Menengah, Jakarta: Rineka Cipta. 